\title{
Diets of shags Phalacrocorax aristotelis and cormorants $P$. carbo in Norway and possible implications for gadoid stock recruitment
}

\author{
R. T. Barrett ${ }^{1}$, N. Røv ${ }^{2}$, J. Loen ${ }^{2}$, W. A. Montevecchi ${ }^{3}$ \\ ${ }^{1}$ Norwegian Institute for Nature Research, c/o Tromsø Museum, University of Tromsø, N-9000 Tromsø, Norway \\ ${ }^{2}$ Norwegian Institute for Nature Research, Tungasletta 2, N-7004 Trondheim, Norway \\ ${ }^{3}$ Depts of Psychology and Biology, and Ocean Sciences Centre, Memorial University of Newfoundland, St. John's, \\ Newfoundland, Canada A1B $3 \times 9$
}

\begin{abstract}
The diets of shags and cormorants were studied in Norway through analyses of regurgitated pellets. Although this method has many limitations, indications were that both species rely heavily on small gadoids (Gadidae) and sand eels (Ammodytidae) for food throughout their range, but also eat other fish species when available. There was considerable dietary overlap between species, despite a tendency for cormorants to eat larger fish and more benthic items than shags. Predation by shags and cormorants could be a factor limiting the recruitment of cod and saithe into what are now severely reduced, but commercially important stocks in the Norwegian and Barents Seas.
\end{abstract}

\section{INTRODUCTION}

There is an increasing awareness of the roles of seabirds in marine ecosystems (e.g. Croxall et al. 1985, Schneider et al. 1986, Croxall 1987) and recent estimates in areas of major seabird concentrations are of substantial energy harvest by these top predators (e.g. Brown \& Nettleship 1982, Furness 1982, Croxall 1987. Cairns et al. 1990). It has also been suggested that seabirds may deplete prey biomass around colonies (Gaston et al. 1983, Furness \& Birkhead 1984, Hunt et al. 1986), direct evidence for which has been presented for double-crested cormorants Phalacrocorax auritus (Birt et al. 1987).

Shags Phalacrocorax aristotelis and cormorants $P$. carbo are large marine birds, ca 2 and $3 \mathrm{~kg}$ respectively, and their daily food consumption has been estimated as 16 to $30 \%$ of body weight (Madsen \& Spärck 1950, Dunn 1975, Johnstone et al. 1990). What and how much these species eat have long been of concern to fishermen, fisheries biologists and, most recently fish farmers (e.g. Steven 1933, Lumsden \& Haddow 1946, Rae 1969, West et al. 1975, Barlow \& Bock 1984, Craven \& Lev 1987, Kennedy \& Johnston 1987, Moerbeek et al. 1987). Concern has however often been based on anecdotal evidence and popular opinion, rather than on scientific study. Although commercial species have repeatedly been found in the diets of shag and cormorants in e.g. Britain, Canada and Australia, their consumption is now usually judged to be inconsequential to fisheries (Lumsden \& Haddow 1946, Rae 1969, West et al. 1975, Pilon et al. 1983, Barlow \& Brock 1984, Trayler et al. 1989).

Saithe Pollachius virens and cod Gadus morhua are both commercially important species in the Norwegian and Barents Seas and are heavily exploited by several nations. In recent years their stocks have dropped considerably - cod by ca $80 \%$ since the early 1950s, saithe by $50 \%$ since 1970 (Anonymons 1989), causing much concern for fisheries managers. As a result, factors affecting gadid recruitment have become a recent focus of research attention (e.g. Loeng 1987), but as yet the potential predation pressure of seabirds has not been considered to be significant. This study investigates avian predation on these fish.

Shags and cormorants breed in colonies all along the Norwegian coast, and breeding populations have recently been estimated to be 15000 and 21000 pairs, respectively (Røv 1984, Røv \& Strann 1986). The breeding ranges of shags and cormorants overlap from Trondheim northwards. Data concerning the diet of shags in Norway are limited to a few samples from 
Hornøy, East Finnmark (Furness \& Barrett 1985, Barrett et al. 1986). Apart from anecdotal data collected by Collett (cited in Madsen \& Spärck 1950) at the turn of the century, the diet of Norwegian cormorants is unknown. The present study further documents the diets of shags and cormorants across most of their Norwegian breeding range through data collected in 1985 to 1989 at 8 shag colonies, 5 cormorant colonies and one cormorant roosting site. The study also assesses the potential effects of these species on commercial fish stocks and expands studies by Lack (1945) and Ainley et al. (1981) of habitat partitioning (diet overlap) among Phalacrocoracidae in areas of sympatry. Comparisons are also made with other studies of shag and cormorant diet in Britain and North America.

\section{MATERIAL AND METHODS}

Cormorants and shags regurgitate pellets of undigested material at least once per day (Ainley et al. 1981, Duffy \& Laurenson 1983, Johnstone et al. 1990), and their contents give a useful indication of what the birds have recently eaten. As a food sampling method, the analysis of pellets has very clear limitations. Pellet contents do not necessarily reflect the complete diet of shags or cormorants, nor do the size of otoliths recovered seem to yield more than a rough approximation, and sometimes, because of digestion, an underestimation, of the size of fish eaten (Ross 1976, Duffy \& Laurenson 1983, Jobling \& Breiby 1986, Gales 1988, Johnstone et al. 1990). These pellets can, however, be sampled cheaply and with a minimum of disturbance. Unless detailed quantitative data are needed for the assessment of complete diet breadth or total food consumption, this method is simple, valuable and far preferable to forcing birds to regurgitate or even killing them (see Duffy \& Jackson 1986 for a review of methods of food sampling). Even though otolith wear can vary from bird to bird or time to time (Johnstone et al. 1990), such pellet analysis is, in our and Duffy \& Laurenson's (1983) opinion, a useful, non-destructive tool with which to study, if only roughly, temporal, spatial and interspecific variations in diet composition.

For this study, pellets regurgitated by incubating or brooding shags were collected over periods of several weeks from nest sites on Hornøy (June to July 1989) and Bleiksøy (July 1985, May to August 1986) in northern Norway (by R. T. B. and W. A. M.) and from 6 breeding colonies (Ferkingstadøyane, Urter, Låtersøy, Melne, Lyngsøy, and Spannholmane) in Rogaland in June and July 1988 (by J. L.) (Fig. 1). Cormorant pellets were collected during single day visits to breeding sites on 3 colonies in East Finnmark ( 2 in Sør-Varanger and 1 in Kongsfjord) in 1989 (by N. R.), on Hovsflesa, in

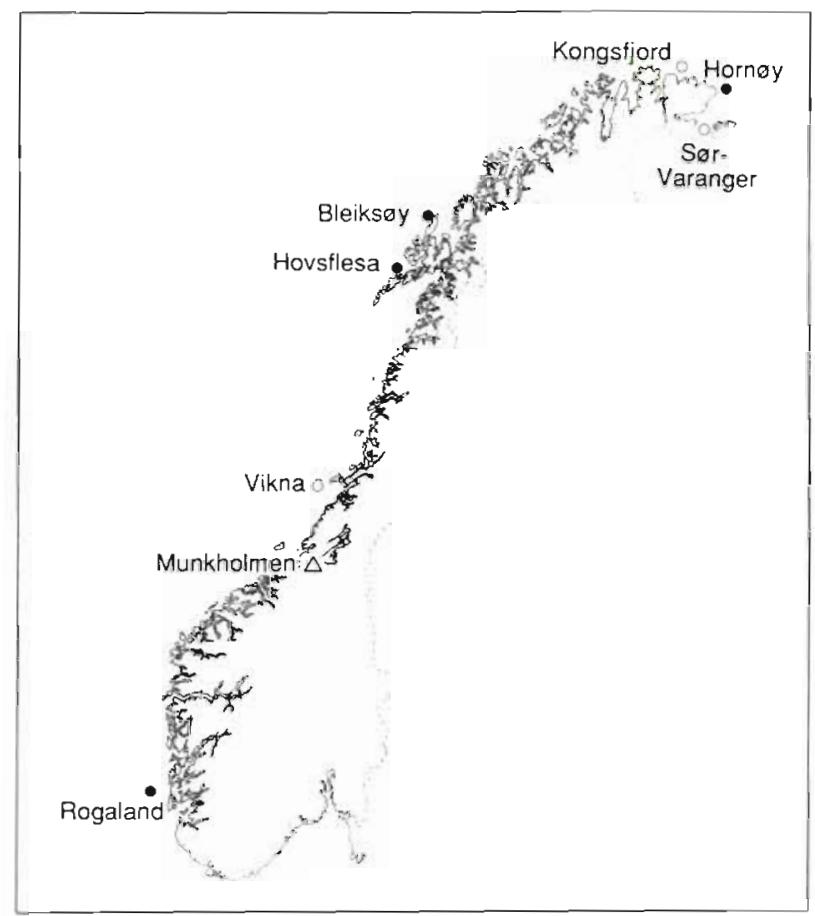

Fig. 1. Localities where shag $(\bullet)$ and cormorant $(\cdots$,$) diets were$ studied in Norway. (Six neighbouring colonies in Rogaland have been pooled). $(0)$ Breeding sites; $(\Delta)$ roost

Lofoten, in July 1985 and July 1986 (R. T. B. and W. A. M.) and at Vikna, Trøndelag in July 1887, and to a roost on Munkholmen, Trondheimsfjord in September and October 1986 (N. R.). Except for those collected in East Finnmark, each pellet was bagged separately and stored either in a deep freezer or in alcohol before being sorted under a binocular microscope in the laboratory by the respective collectors. East Finnmark samples were collected and frozen in a single bag for each colony.

Fish were identified to lowest possible taxon by sagittal otoliths (using Breiby 1985, Härkönen 1986. and our own otolith collections), invertebrates by various hard parts (e.g. chitinous mandibles of polychaetes, carapaces/chelae of crabs). Otoliths of small cod Gadus morhua and saithe Pollachius virens are very similar in appearance and when difficult to distinguish were pooled as Gadidae. No attempt was made to pair otoliths, but the number from each species or group and the number of paired invertebrate organs (e.g. mandibles) in each pellet were counted. In an attempt to reduce biases induced by measuring partially digested otoliths (Jobling \& Breiby 1986, Gales 1988, Johnstone et al. 1990) only otoliths which did not show signs of excessive digestion/wear were measured using a calibrated ocular grid in the microscope (R.T.B.), digital vernier calipers (J. L.) or $\mathrm{mm}$ graph paper under the microscope (N. R.). Minimal fish length was calculated from published data relating otolith size to fish 
length (Jobling \& Breiby 1986 for gadoids and sand eels Ammodytes spp., Härkönen 1986 for bull-rout Myoxocephalus scorpius). For small cod and saithe, the relationships between otolith length and standard length are very similar, and the mean of the 2 was used to estimate the standard length of unidentified gadoids (Table 1). Even if data are biased due to otolith erosion, direct comparisons of the size of fish caught by cormorants and shags can be made on the assumption that the degree of erosion is similar in these closely related species.

Results are presented numerically using the frequency of occurrence of each taxon (the number of pellets containing each taxon) and the numerical frequency of each taxon (the number of individuals of each taxon; Hyslop 1980). Although such a numerical presentation would overemphasize the number of prey items containing hard parts regurgitated in the pellets (e.g. otoliths and polychaete mandibles) and underestimate the number of possible soft-bodied animals which would be nearly totally digested, e.g. crustaceans (Johnstone et al. 1990), previous studies of whole stomachs or stomach regurgitations all show a predominance of fish in both shags and cormorants (Steven 1933, Lumsden \& Haddow 1946, Madsen \& Spärck 1950, van Dobben 1952, Pearson 1968, West et al. 1975 , Ross 1976). Bounded by limitations of differential erosion and digestion of otoliths according to species and original size (Ross 1976, Duffy \& Laurenson 1983, Johnstone et al. 1990), pellet analyses yield useful indications of dietary differences among colonies and species.

Assuming that the degree of erosion and loss of otoliths were the same in both species, such that absolute values for each species or locality may be misleading, a comparison of the relative values can be justified, e.g. through calculation of Morisita's index of diet overlap (Horn 1966, Diamond 1983). Our analysis was based on the percentage by number of each fish family (Level 3 of Diamond 1983) and of the classes Polychaeta, Crustacea and Echinoidea. Similarly, Shannon-Weaver diversity indices (Tramer 1969) were also calculated for each locality at the family level. Molluscs were excluded from both sets of calculations (see 'Results'). All statistical tests were carried out using MINITAB statistical package (Ryan et al. 1985).

\section{RESULTS}

Totals of 6184 and 1635 identifiable animal body parts were isolated from 204 shag and ca 100 cormorant pellets, respectively. Although overlap indices comparing the Ferkinstadøyene samples with other Rogaland samples were low $(0.66$ to 0.73$)$ due to the relatively high frequency $(41 \%)$ of sand eels, compared to 1 to $6 \%$ in the other colonies, all Rogaland shag samples, and also the East Finnmark cormorant samples, were pooled due to small sample size from individual localities. There was no apparent seasonal variation in shag diet composition on Bleiksøy between May and August 1986 (overlap indices $=0.95$ to 0.99 ); these data were also pooled.

\section{Diet composition}

Fish were the most important prey of both species but more benthic fauna including relatively large numbers of molluscs and crabs were found in cormorant pellets (Tables 2 to 5). Whether the molluscs were eaten directly by the cormorants or whether they were from the diet of e.g. the gadoids is uncertain. Helcion pellucidum, for example, are small $(<1 \mathrm{~cm})$ limpets which live firmly attached to Laminaria spp. and are a common prey for small coastal cod (W. Vader unpubl.). It is thus likely that they were a by-product of gadoid prey. In our analyses we assumed that molluscs were not eaten directly by shags or cormorants. In the Hovsflesa samples, the crabs were almost completely articulated and so large (carapace width 10 to $36 \mathrm{~mm}$ ) that it is probable that they were avian prey.

Of the 5657 otoliths from shag pellets, only 121 $(2.1 \%)$ were too eroded for identification, whereas 58 $(5.1 \%)$ of the 1139 otoliths from cormorant pellets were unidentifiable. Otoliths from 11 families of fish were identified, but gadoids dominated the samples from both species (Figs. 2 and 3). The gadid otoliths we could identify suggested a dominance of saithe in the shag samples from Bleiksøy and the cormorant samples from Hovsflesa and Vikna, and of cod in the Munkholmen and East Finnmark samples. Otoliths of 2 large (ca $35 \mathrm{~cm}$ ) haddock Melanogrammus aeglefinus were also

Table 1. Linear relationships between otolith length $(\mathrm{OL})$ and standard fish length (SL)

\begin{tabular}{|lll|}
\hline Species & Equation & Source \\
\hline Cod Gadus morhua & $\mathrm{SL}=0.41+22.44 \mathrm{OL}$ & Jobling \& Breiby (1986) \\
Saithe Pollachius virens & $\mathrm{SL}=-4.24+23.5 \mathrm{OL}$ & Jobling \& Breiby (1986) \\
Gadid = (cod + saithe)/2 & $\mathrm{SL}=-1.68+22.9 \mathrm{OL}$ & Jobling \& Breiby (1986) \\
Sand eel Ammodytes tobianus & $\mathrm{SL}=14.93+50.81 \mathrm{OL}$ & Härkönen (1986) \\
Bull-rout Myoxocephalus scorpius & $\mathrm{SL}=-9.95+34.8 \mathrm{OL}$ & \\
\hline
\end{tabular}


Table 2. Phalacrocorax aristotelis. Frequency of occurrence (no. of pellets containing each item) of food items in shag pellets at Hornøy (1989), Bleiksøy $(1985,1986)$ and Rogaland (1988)

\begin{tabular}{|c|c|c|c|c|}
\hline & Horney & $\begin{array}{r}\text { Blei } \\
1985\end{array}$ & $\begin{array}{l}\text { ksøy } \\
1986\end{array}$ & Rogaland \\
\hline No. of peilets & 26 & 42 & 79 & 57 \\
\hline Clupeidae (unident.) & 0 & 0 & 4 & 1 \\
\hline \multicolumn{5}{|l|}{ Osmeridae } \\
\hline Mallotus villosus & 1 & 0 & 2 & 0 \\
\hline \multicolumn{5}{|l|}{ Myctophidae } \\
\hline Benthosema glaciale & 0 & 1 & 0 & 0 \\
\hline Gadidae (unident.) & 20 & 39 & 71 & 41 \\
\hline Trisopterus sp. & 0 & 0 & 0 & 17 \\
\hline Labridae (unident.) & 0 & 0 & 0 & 36 \\
\hline \multicolumn{5}{|l|}{ Ammodytidae } \\
\hline \multicolumn{5}{|l|}{ Anarhichadidaè } \\
\hline Anarhichas sp. & 1 & 0 & 0 & 0 \\
\hline \multicolumn{5}{|l|}{ Scorpaenidae } \\
\hline Sebastes sp. & 6 & 1 & 5 & 6 \\
\hline \multicolumn{5}{|l|}{ Cottidae } \\
\hline Myoxocephalus scorpius & 0 & 9 & 32 & 0 \\
\hline Pleuronectidae (unident.) & 0 & 3 & 3 & 0 \\
\hline Unident. fish & 2 & 9 & 13 & 20 \\
\hline \multicolumn{5}{|l|}{ Polychaetes } \\
\hline Nereis sp. & 0 & 25 & 21 & 21 \\
\hline Polynoidae & 1 & 2 & 6 & 0 \\
\hline Isopoda & 1 & 0 & 0 & 0 \\
\hline Decapoda & 4 & 0 & 17 & 22 \\
\hline Gastropoda & 0 & 0 & 3 & 0 \\
\hline
\end{tabular}

found in the Munkholmen samples. Another apparently important prey of both shags and cormorants was sand eel Ammodytes sp. which was numerous at all shag localities and in cormorant samples from East Finnmark (Figs. 2 and 3). Mandibles of polychaetes (mostly Nereis, but also some Polynoidae) were also frequent in most samples (Tables 2 to 5). Although they too could have originated from the stomachs of fish eaten by birds, it is also possible that they were caught during their periodic pelagic swarming phase (Hartmann-Schröder 1971). This speculation is strengthened by the fact that polychaetes were common in the cormorant samples from Hovsflesa in 1985 but were completely absent in 1986 in an otherwise similar food spectrum (Tables 4 and 5. Fig. 3)

All indices of dietary overlap among all shag localities were relatively high (Table 6) suggesting a narrow and consistent diet. Gadoids and sand eels together dominated at all localities although shags relied more heavily on sand eels on Hornoy than at other colonies (Fig. 2). Bull-rout Myoxocephalus scorpius was found on Bleiksøy only, while Trisopterus sp. and wrasse (Labridae) only occurred in the Rogaland samples. Of the crustaceans recorded, the Hornoy and
Rogaland samples contained remains of prawns (Natantia)/euphausiids while those from Bleiksøy 1986 were of crabs (Brachyura and Anomura).

Of identified prey in all the cormorant samples, 23 to $70 \%$ were gadoids, the highest values being found in Trøndelag (Fig. 3). Sand eels and capelin were only found in East Finnmark where redfish Sebastes sp. and salmonids were also common. There was a tendency for cormorants in East. Finnmark to have a more varied diet $(5$ fish species each contributing to $>5 \%$ of diet) than at the other localities (Fig. 3) resulting in the highest diversity index and the lowest mean overlap index for any one locality (Table 6). For shags, diet breadth increased from north to south (Table 6).

\section{Size of fish eaten}

Cormorants took larger gadoids than shags (Fig. 4, Table 7; Mann-Whitney $U=5.9 \times 10^{6}, p<0.001$ ). There was a remarkable correspondence between the bimodal length frequency distribution of fish caught by shags and the known sizes of juvenile saithe and cod from northern waters (Fig. 5). This, and the minimal erosion of cod otoliths recorded in shags by Johnstone et al. (1990) suggest that, in the case of gadoids at least, our estimations of fish size are reasonable. If so, it seems that shags prey mainly on 0 - and I-group fish while cormorants also catch II-group fish. Few 0 -group gadoids were recorded for either species in East Finnmark. A detailed breakdown of the Bleiksoy data revealed a shift in year-class predominance (from 0 in 1985 to I in 1986; Table 7) which may be related to a lower spawning success of saithe in 1986 (Nedreaas \& Smedstad 1987, R. T. B. unpubl.).

Cormorants also took larger Myoxocephalus scorpius than shags in the Vesteralen/Lofoten region (Bleiksøy/ Hovsflesa, Mann-Whitney $U=1.1 \times 10^{4}, p<0.001$ ), but smaller sand eels in East Finnmark (Fig. 6, Table 7; Mann-Whitney $\mathrm{U}=3672, \mathrm{p}<0.001$ )

There is a good probability that many of the sand eel otoliths were indeed eroded before regurgitation (Johnstone et al. 1990), yet the length frequency distributions of sand eels caught at the 3 shag localities were all similar (median 100 to $130 \mathrm{~mm}$, range ca 80 to $160 \mathrm{~mm}$; Table 7, Fig. 6) and fell within the approximate size range of I- to IV-group fish (Reay 1970).

\section{Harvest of gadoids}

The daily energy expenditure (DEE) of shags and cormorants can be calculated on the assumption that free-living birds require ca $3 \times$ basal metabolic rate (BMR) (Birt-Friesen et al. 1989, Furness 1990). BMR 
Table 3. Phalacrocorax aristotelis. Numerical frequency of food remains in shag pellets at Hornøy (1989), Bleiksøy (1985, 1986) and Rogaland (1988)

\begin{tabular}{|c|c|c|c|c|}
\hline & \multirow[t]{2}{*}{ Horney } & \multicolumn{2}{|c|}{ Bleiksøy } & \multirow[t]{2}{*}{ Rogaland } \\
\hline & & 1985 & 1986 & \\
\hline \multicolumn{5}{|l|}{ Fish otoliths } \\
\hline Clupeidae (unident.) & 0 & 0 & 7 & 2 \\
\hline \multicolumn{5}{|l|}{ Osmeridae } \\
\hline Mallotus villosus & 1 & 0 & 3 & 0 \\
\hline \multicolumn{5}{|l|}{ Myctophidae } \\
\hline Benthosema glaciale & 0 & 2 & 0 & 0 \\
\hline Gadidae (unident.) & 323 & 1884 & 1120 & 401 \\
\hline Trisopterus sp. & 0 & 0 & 0 & 102 \\
\hline Labridae (unident.) & 0 & 0 & 0 & 205 \\
\hline \multicolumn{5}{|l|}{ Ammodytidae } \\
\hline Ammodytes sp. & 450 & 126 & 529 & 152 \\
\hline \multicolumn{5}{|l|}{ Anarhichadidae } \\
\hline Anarhichas sp. & 2 & 0 & 0 & 0 \\
\hline \multicolumn{5}{|l|}{ Scorpaenidae } \\
\hline Sebastes sp. & 13 & 3 & 34 & 17 \\
\hline \multicolumn{5}{|l|}{ Cottidae } \\
\hline Myoxocephalus scorpius & 0 & 14 & 141 & 0 \\
\hline Pleuronectidae (unident.) & 0 & 3 & 4 & 0 \\
\hline Unident fish & 2 & 12 & 44 & 63 \\
\hline \multicolumn{5}{|l|}{ Other } \\
\hline \multicolumn{5}{|l|}{ Polychaetes } \\
\hline Nereis sp. & 0 & 273 & 92 & 50 \\
\hline Polynoidae & 3 & 8 & 44 & 0 \\
\hline Isopoda & 2 & 0 & 0 & 0 \\
\hline Decapoda & 5 & 0 & 22 & 20 \\
\hline Gastropoda & 0 & 0 & 6 & 0 \\
\hline Totals & 801 & 2325 & 2044 & 1014 \\
\hline
\end{tabular}

was calculated from the allometric equation for seabirds at any latitude, $\mathrm{BMR}=433.5 \mathrm{~m}^{0.734}$ where $\mathrm{m}=$ body weight in $\mathrm{kg}$ (Gabrielsen et al. in press). Body weights (shags $=1800 \mathrm{~g}$, cormorants $=3250 \mathrm{~g}$ ) were taken from own unpublished data and Cramp \& Simmons (1977). Quantities of fish consumed were calculated from DEE using a value of $85 \%$ for assimilation efficiency (Dunn 1975) and a calorific value for gadoids and other small fish of $5.5 \mathrm{~kJ} \mathrm{~g}^{-1}$ (Barrett et al. 1987 . unpubl.). Using these relationships, the daily food consumptions of shags and Cormorants are calculated to be 430 and $661 \mathrm{~g}$ fish repectively. These weights are equivalent to 24 and $20 \%$ of body weight respectively, and similar to the $22 \%$ reached for freeliving shags calculated from Furness (1990). Because metabolic rate increases with activity (Birt-Friesen et al. 1989), the lower values (16 to $18 \%$ ) recorded for captive shags and white-breasted comorants Phalacrocorax lucida by Johnstone et al. (1990) and Junor (1972) are probably a result of constraint.

Based on breeding populations of 30000 shags and 42000 cormorants, the monthly harvest by breeding adults will thus be ca 400 tonnes (shag) and 850 tonnes (cormorant), yielding totals of ca 1600 and 3400 tonnes respectively during the main breeding season (April to July). Assuming the proportion of gadoids taken is ca $50 \%$ (this study - allowing for the more rapid digestion of e.g. sand eel otoliths) and that it is the same throughout the breeding season, this gives a total consumption of gadoids of ca 6000 tonnes by adults of both species (including breeders and nonbreeders; latter based on population parameters given in Table 8 and assuming immature birds have the same diet as adults) during the breeding season.

An alternative calculation can be based on the number of gadoid otoliths found in each pellet (ca 20 for shags, 10 for cormorants; Tables 1 to 4 ), the size (and hence weight using a condition factor $=1$ ) of fish from each locality and the assumptions that (1) each bird produces one pellet per day, (2) there is little erosion of gadoid otoliths and (3) that only $67 \%$ of the gadoid otoliths are regurgitated in the pellets (Jobling \& Breiby 1986, Johnstone et al. 1990). This results in a daily consumption of 15 gadoids weighing $0.17 \mathrm{~kg}$ by 
Table 4. Phalacrocorax carbo. Frequency of occurrence of food items in cormorant pellets at Hovsflesa (1985, 1986), Munkholmen (1986) and Vikna (1987)

\begin{tabular}{|c|c|c|c|c|}
\hline & \multicolumn{2}{|c|}{ Hovsflesa } & \multirow[t]{2}{*}{ Munkholmen } & \multirow[t]{2}{*}{ Vikna } \\
\hline & 1985 & 1986 & & \\
\hline No. of peliets & 17 & 21 & 16 & 13 \\
\hline \multicolumn{5}{|l|}{ Clupeidae } \\
\hline Clupea harengus & 0 & 1 & 0 & 0 \\
\hline \multicolumn{5}{|l|}{ Salmonidae } \\
\hline Salmo sp. & 0 & 0 & 0 & 1 \\
\hline Gadidae (unident.) & 14 & 17 & 9 & 13 \\
\hline Gadus morhua & 0 & 0 & 13 & 0 \\
\hline Melanogrammus aeglefinus & 0 & 1 & 2 & 0 \\
\hline Pollachius virens & 0 & 0 & 1 & 0 \\
\hline Trisopterus sp. & 0 & 0 & 2 & 0 \\
\hline Labridae (unident.) & 0 & 0 & 1 & 0 \\
\hline \multicolumn{5}{|l|}{ Anarhichadidae } \\
\hline Anarhichas sp. & 2 & 2 & 0 & 0 \\
\hline \multicolumn{5}{|l|}{ Scorpaenidae } \\
\hline Sebastes sp. & 1 & 3 & 0 & 0 \\
\hline \multicolumn{5}{|l|}{ Cottidáe } \\
\hline Myoxocephalus scorpius & 7 & 5 & 0 & 1 \\
\hline Pleuronectidae (unident.) & 4 & 2 & 4 & 2 \\
\hline Unident. fish & 3 & 3 & 1 & 1 \\
\hline Polychaetes & 10 & 0 & 7 & 1 \\
\hline Isopoda & 0 & 1 & 0 & 0 \\
\hline Natantia & 0 & 1 & 0 & 0 \\
\hline Hyas spp. & 9 & 5 & 0 & 0 \\
\hline Pagurus bernhardus & 1 & 8 & 0 & 0 \\
\hline Unident. crab & 2 & 1 & 7 & 4 \\
\hline Loricata & 1 & 2 & 0 & 0 \\
\hline Gastropoda & 6 & 11 & 5 & 3 \\
\hline Helcion pellucidum & 4 & 2 & 0 & 0 \\
\hline Lamellibranchia & 1 & 2 & 3 & 5 \\
\hline Echinoidea & 5 & 5 & 0 & 3 \\
\hline
\end{tabular}

shags and 7.5 gadoids weighing $0.33 \mathrm{~kg}$ by cormorants, or 600 and 1700 tonnes during the same 4 mo respectively. Again assuming immature birds have the same diet, their consumption is calculated to ca 4000 tonnes Either way, it seem reasonable to suggest that Norwegian shags and cormorants consume on the order of 6000 tonnes of 0-, I- and II-group cod or saithe during the breeding season.

In actual numbers, breeding shags may take as many as $55 \times 10^{6}$ and cormorants $40 \times 10^{6}$ gadoids per season. Estimates based on Figs. 4 and 5 show that of the gadoids eaten by shags, $65 \%$ are 0 -group and $34 \%$ Igroup. For cormorants, $38 \%$ are 0 -group, $50 \%$ I-group and $11 \%$ II-group giving a total harvest of $50 \times 10^{6} 0$ group, $40 \times 10^{6} \mathrm{I}$-group and $4 \times 10^{6} \mathrm{II}$-group gadoids by both species. Including immature birds would raise these totals to 144,110 and $12 \times 10^{6}$ respectively. Given the close agreement of the results of both biomass calculations and that shags and cormorants are generally heavy predators on gadoids, these values are probably in the correct order of magnitude.

\section{DISCUSSION}

Recognizing the limitations of the pellet analyses used, shags and cormorants must rely heavily on small fish for food in summer and autumn throughout their range in Norway. Although the numbers of polychaetes found in the cormorant pellets in Lofoten and Trøndelag were relatively high, their contribution to the species' diet as it appears when expressed numerically in Fig. 3 is exaggerated. If it was expressed gravimetrically they would contribute little to overall diet. A single polychaete weighs ca 1 to $2 \mathrm{~g}$ compared to a median gadoid of $150 \mathrm{~mm}$ length and a biomass of ca $30 \mathrm{~g}$ (based on a fish with a condition factor (CF) of $1, C F \times$ mass $=1^{3} / 100$ where $1=$ length in $\mathrm{cm}$ ). Polychaetes are normally sedentary with short, periodic swarming phases during the spawning season (HartmannSchröder 1971) such that they are often not available to pelagic predators. Furthermore, when they do swarm they do so in such large numbers that they could contribute an unrealistically high proportion of 
Table 5. Phalacrocorax carbo. Numerical frequency of food items in cormorant pellets at East Finnmark (1989), Hovsflesa (1985, 1986), Munkholmen (1986) and Vikna (1987)

\begin{tabular}{|c|c|c|c|c|c|}
\hline & $\begin{array}{c}\text { East } \\
\text { Finnmark }\end{array}$ & 1985 & 1986 & Munkholmen & Vikna \\
\hline \multicolumn{6}{|l|}{ Fish otoliths } \\
\hline \multicolumn{6}{|l|}{ Clupeidae } \\
\hline Clupea harengus & 0 & 0 & 2 & 0 & 0 \\
\hline \multicolumn{6}{|l|}{ Salmonidae } \\
\hline Salmo sp & 39 & 0 & 0 & 0 & 2 \\
\hline \multicolumn{6}{|l|}{ Osmeridae } \\
\hline Mallotus villosus & 103 & 0 & 0 & 0 & 0 \\
\hline Gadidae (unident.) & 0 & 104 & 156 & 26 & 93 \\
\hline Gadus morhua & 155 & 0 & 0 & 92 & 0 \\
\hline Melanogrammus aeglefinus & 0 & 0 & 3 & 2 & 0 \\
\hline Pollachius virens & 2 & 0 & 0 & 1 & 0 \\
\hline Trisopterus sp. & 0 & 0 & 0 & 3 & 0 \\
\hline Labridae (unident.) & 0 & 0 & 0 & 1 & 0 \\
\hline \multicolumn{6}{|l|}{ Ammodytidae } \\
\hline Ammodytes sp. & 123 & 0 & 0 & 0 & 0 \\
\hline \multicolumn{6}{|l|}{ Anarhichadidae } \\
\hline Anarhichas sp. & 0 & 3 & 2 & 0 & 0 \\
\hline \multicolumn{6}{|l|}{ Scorpaenidae } \\
\hline Sebastes sp. & 59 & 2 & 7 & 0 & 0 \\
\hline \multicolumn{6}{|l|}{ Cottidae } \\
\hline Myoxocephalus scorpius & 21 & 29 & 14 & 0 & 1 \\
\hline Pleuronectidae (unident.) & 0 & 5 & 4 & 5 & 2 \\
\hline Unident. otoliths & 32 & 17 & 5 & 2 & 2 \\
\hline \multicolumn{6}{|l|}{ Other } \\
\hline Polychaete jaws & 0 & 86 & 0 & 15 & 1 \\
\hline Isopoda & 0 & 0 & 1 & 0 & 0 \\
\hline Natantia & 0 & 0 & 1 & 0 & 0 \\
\hline Hyas spp. & 0 & 19 & 8 & 0 & 0 \\
\hline Pagurus bernhardus & 0 & 1 & 15 & 0 & 0 \\
\hline Unident crab & 0 & 2 & 1 & 7 & 4 \\
\hline Loricata & 0 & 1 & 2 & 0 & 0 \\
\hline Gastropoda & 0 & 38 & 20 & 5 & 25 \\
\hline Helcion pellucidum & 0 & 135 & 60 & 0 & 0 \\
\hline Lamellibranchia & 0 & 1 & 3 & 18 & 9 \\
\hline Echinoidea & 0 & 6 & 9 & 0 & 3 \\
\hline Totals & 534 & 449 & 313 & 177 & 142 \\
\hline
\end{tabular}

diet over a period of only a few days. That our single day collecting trips at Cormorant colonies only sometimes coincided with such swarming periods may explain the absence of polychaetes in the samples from Hovsflesa in 1986 and from East Finnmark in 1989. During the same period that cormorant pellets were sampled on Hovsflesa in 1986, only 10 polychaete mandibles (of a total of 136 collected that year; Table 3) were found on Bleiksøy (on 6 to 15 July 1986) in 4 of 18 shag pellets. It seems that cormorants rely heavily on gadoids in Lofoten and Trondelag, while in Finnmark other fish species (especially capelin and sand eels) are equally important dietary items (Fig. 3) resulting in the highest diversity index of the localities studied (Table 6)

The importance of gadoids in the diet of shags and cormorants in Norway reflects the summer distribution of small cod and saithe. While juvenile (0-and I-group) saithe remain inshore all year, immature coastal cod move into shallow, coastal feeding areas in summer (Bergstad et al. 1987), and thus enter the normal foraging range limits of both avian species $(20$ to $50 \mathrm{~km}$ Cramp \& Simmons 1977). Furthermore, while all ageclasses of both species may be present in large numbers along the west and northwest coasts of Norway (where the main spawning areas occur; Bergstad et al 1987), it is likely that fewer young fish will be available in East Finnmark where coastal spawning populations are much smaller. This would explain the paucity of younger stages in the diets of shags and cormorants in this region (Fig. 4). Wrasse have a similar seasonal 

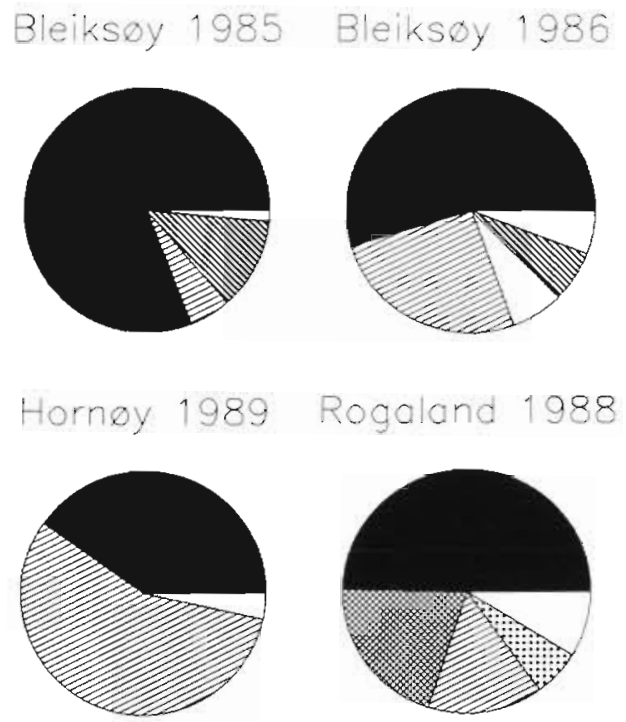

Fig. 2. Phalacrocorax aristotelis. Proportion (by number) of the most common prey eaten by shags in Norway. For explanation of symbols, see Fig. 3

migration, moving into coastal waters from offshore wintering areas in summer (Pethon 1985), but because their northern limit of distribution is western Norway, they only appear in Rogaland samples. Similarly capelin is a cold water species whose distribution is confined to northern waters, and it is rarely found in seabird diets south of Finnmark (Barrett et al. 1987 , R. T. B. unpubl.).

In East Finnmark, capelin is abundant and is an important prey for nearly all seabirds breeding in the
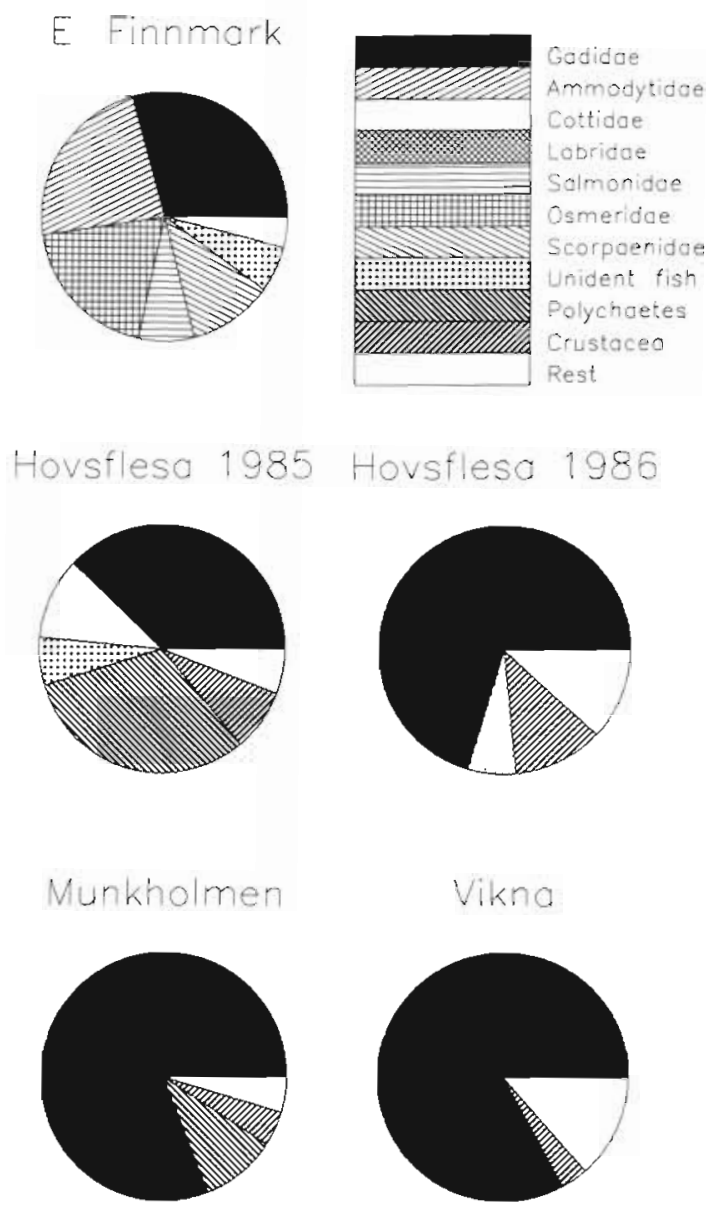

Fig. 3. Phalacrocorax carbo. Proportion (by number) of the most common prey eaten by cormorants in Norway

Table 6. Phalacrocorax aristotelis and $P$. carbo. Intercolony overlap (Morisita's index) in and diversity (Shannon-Weaver index) of the diets of Norwegian cormorants and shags

\begin{tabular}{|c|c|c|c|c|c|c|c|}
\hline \multirow[t]{2}{*}{ Cormorant } & \multicolumn{6}{|c|}{ Morisita's index } & \multirow{2}{*}{$\begin{array}{l}\text { S.-W } \\
\text { index }\end{array}$} \\
\hline & Finnm & Hov 85 & Hov 86 & & Munk & Vikna & \\
\hline East Finnmark & & 0.51 & \multicolumn{2}{|l|}{0.61} & 0.57 & 0.56 & 0.70 \\
\hline Hovsflesa 1985 & & & \multicolumn{2}{|l|}{0.74} & 0.76 & 0.68 & 0.63 \\
\hline Hovsflesa 1986 & & & & & 0.97 & 0.93 & 0.46 \\
\hline Munkholmen & & & & & & 0.99 & 0.30 \\
\hline Vikna & & & & & & & 0.25 \\
\hline Mean & 0.56 & 0.67 & 0.81 & & 0.81 & 0.79 & 0.47 \\
\hline Overall overlap mean. 072 & & & & & & & \\
\hline \multirow[t]{2}{*}{ Shag } & \multicolumn{6}{|c|}{ Morisita's index } & \multirow{2}{*}{$\begin{array}{l}\text { S. }-W . \\
\text { index }\end{array}$} \\
\hline & Hornøy & Bl 85 & & Bl 86 & & Rog & \\
\hline \multirow{2}{*}{\multicolumn{2}{|c|}{$\begin{array}{l}\text { Hornøy } \\
\text { Bleiksøy } 1985\end{array}$}} & \multirow[t]{4}{*}{0.62} & \multirow{2}{*}{\multicolumn{3}{|c|}{$\begin{array}{l}0.86 \\
0.89\end{array}$}} & 0.73 & 0.37 \\
\hline & & & & & & 0.86 & 0.27 \\
\hline \multirow{2}{*}{\multicolumn{2}{|c|}{$\begin{array}{l}\text { Bleiksøy } 1986 \\
\text { Rogaland }\end{array}$}} & & & & & \multirow[t]{2}{*}{0.91} & 0.52 \\
\hline & & & & & & & 0.56 \\
\hline \multicolumn{2}{|l|}{$\begin{array}{l}\text { Mean } \\
\text { Overall overlap mean: } 0.81\end{array}$} & 0.79 & \multicolumn{3}{|c|}{0.87} & 0.83 & 0.43 \\
\hline
\end{tabular}




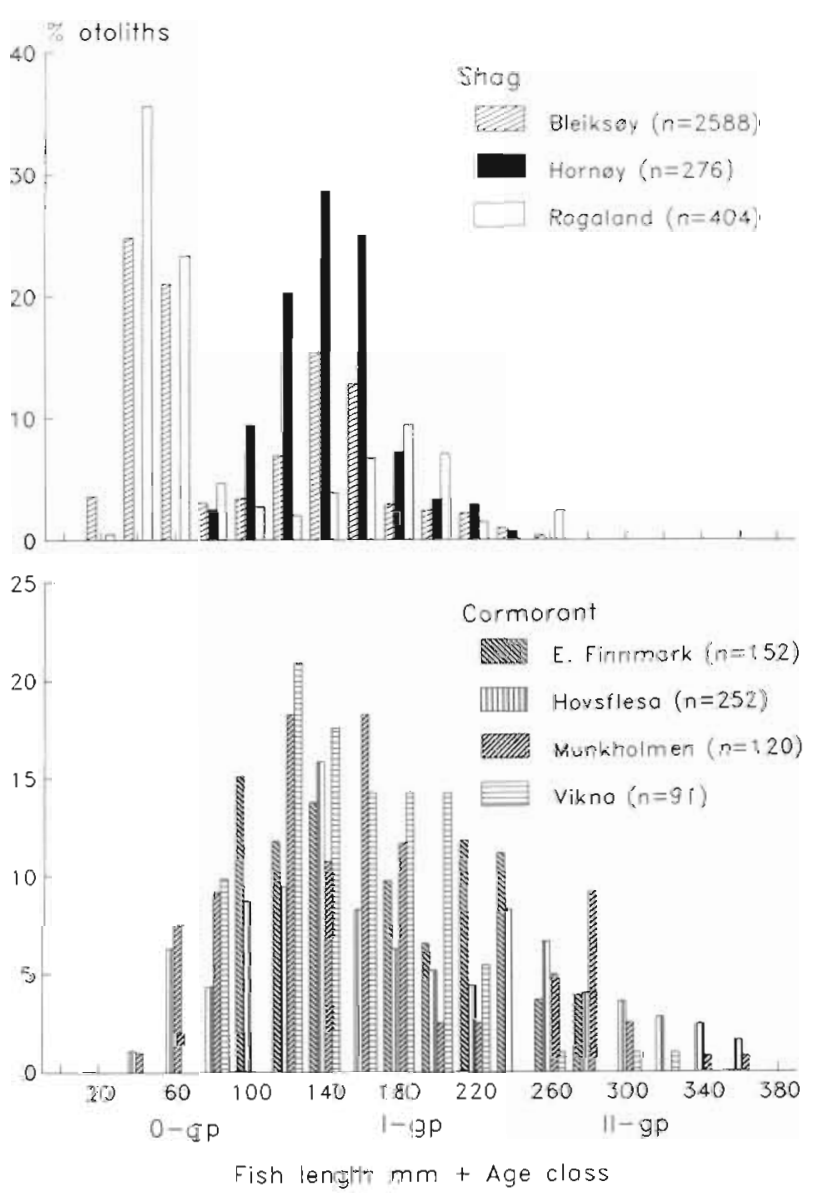

Fig. 4. Length frequency distribution of gadoids eaten by shags and cormorants in Norway

region (Furness \& Barrett 1985, Barrett \& Furness 1990). While capelin is eaten by cormorants (this study), it has never appeared in shag samples (includ-

Table 7. Median lengths ( $\mathrm{mm}$ ) of the commonest fish caught by shags and cormorants in Norway (no. of otoliths in parentheses)

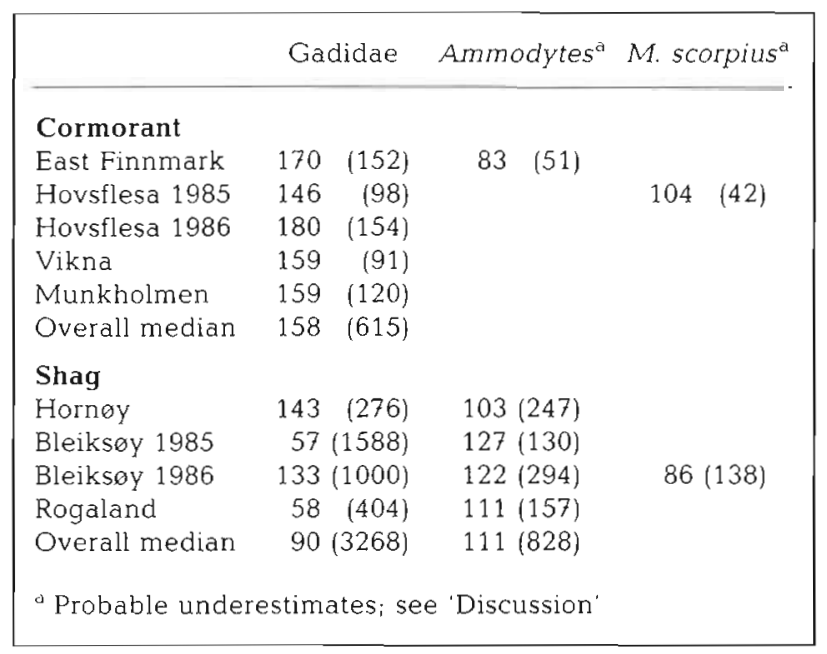

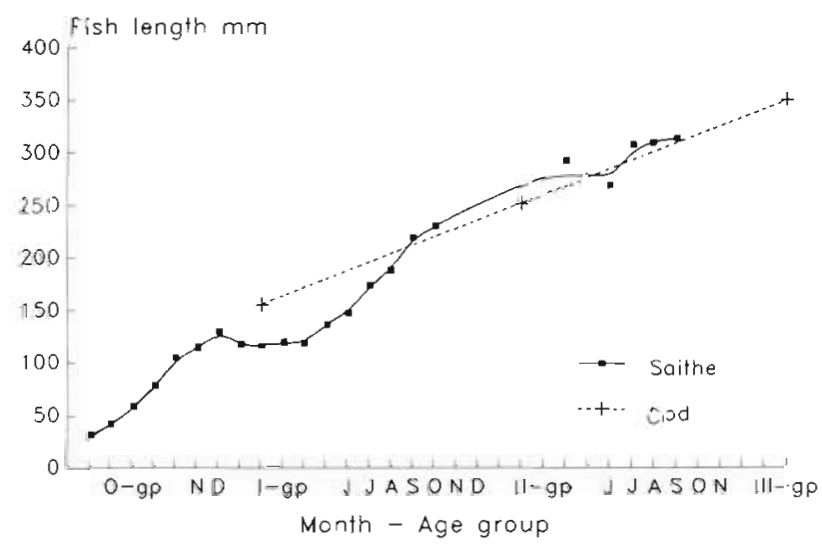

Fig. 5. Pollachius virens and Gadus morhua. Growth of juvenile saithe and cod in the Barents Sea. (After Mironova 1961, Nakken \& Raknes 1987)

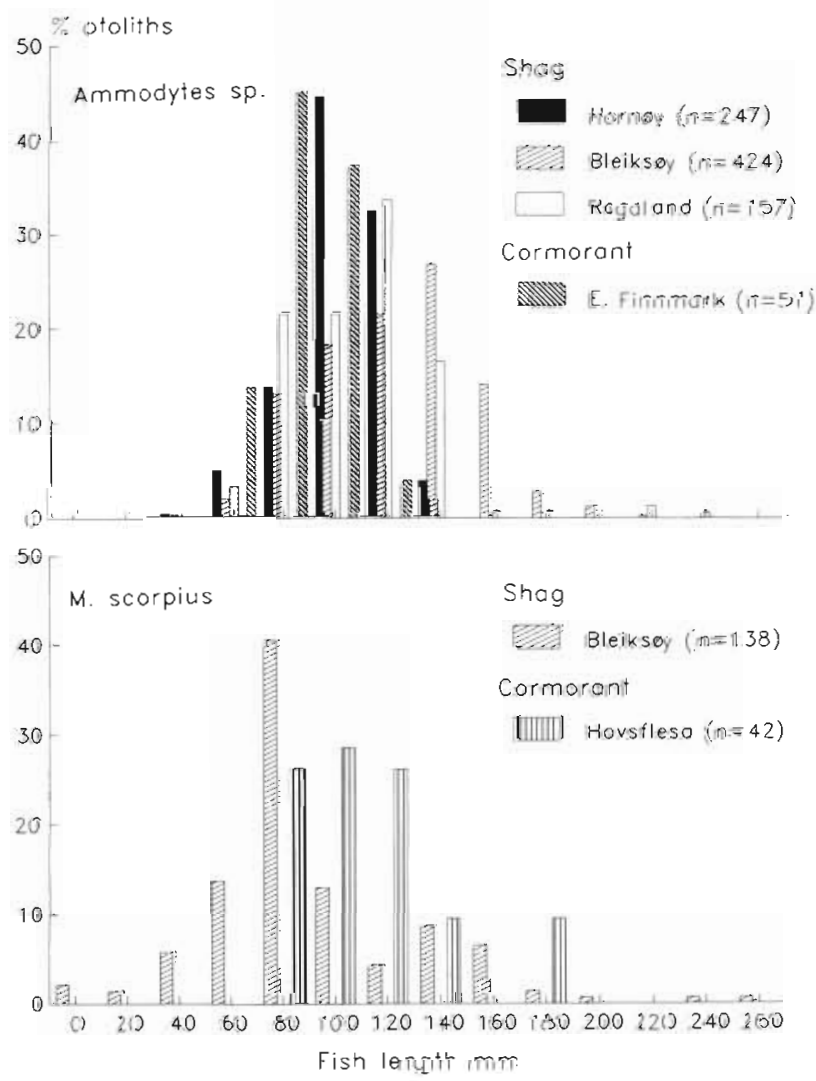

Fig. 6. Minimum length frequency distributions of sand eels Ammodytidae and bull-rout Myoxocephalus scorpius eaten by shags and cormorants in Norway. (Lengths probably underestimated - see text)

ing adult and chick regurgitations collected on Hornøy since 1980; Furness \& Barrett 1985, Barrett et al. 1986, this study). Capelin shoal throughout the water column and are caught close to Hornøy by deep divers (guillemots Uria spp.), shallow divers (puffins Fratercula arctica, black guillemots Cepphus grylle) and surface feeders (kittiwakes Rissa tridactyla, gulls Laridae (Fur- 
Table 8. Phalacrocorax aristotelis and P. carbo. Population parameters of shags and cormorants used to calculate numbers of individuals in Norway in the breeding season

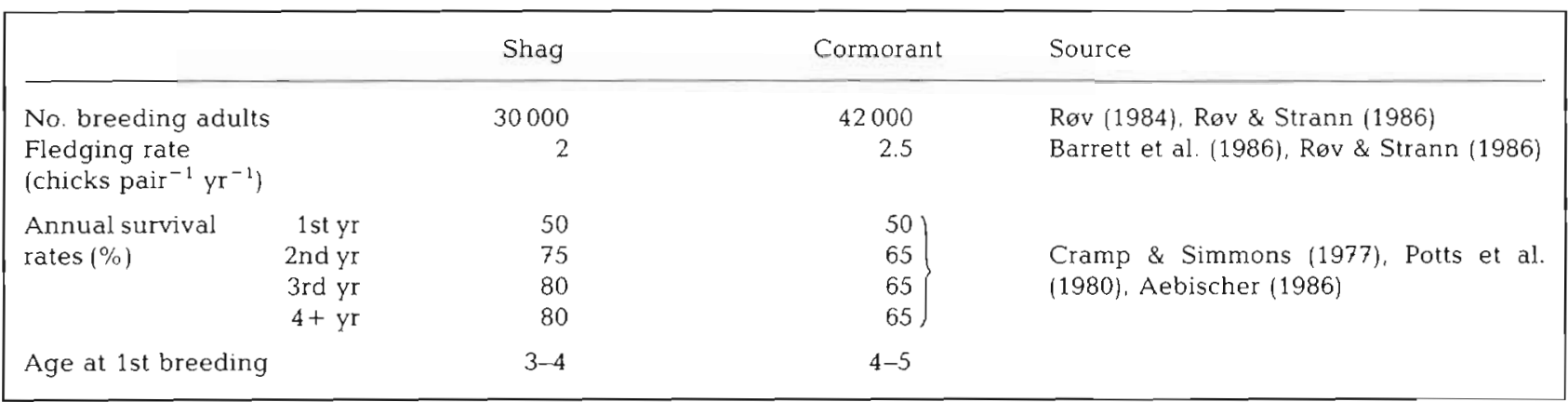

ness \& Barrett 1985, Barrett \& Furness 1990) and should thus be available to shags. Capelin otoliths are hyaline and therefore more rapidly digested than those of gadoids (Jobling \& Breiby 1986), but it is unlikely that they would be totally digested by shags and not by cormorants.

Consistent with earlier studies (summarized in Cramp \& Simmons 1977), this study suggests that Norwegian shags have a more restricted diet breadth (a slightly lower mean diversity index) than cormorants (Tables 6 and 9) and that cormorants feed more on or near the seabed than shags. Gadoids and sand eels appeared to be shags' commonest prey throughout their range, while cormorants, at least in East Finnmark, tended to be more opportunistic. Overlap indices between species were however higher in East Finnmark and in the Lofoten/Vesterålen area than from areas in sympatry in Great Britain (Table 9). Three of the 4 British studies were carried out in estuarine habitats, and in all 4 cormorants ate a higher proportion of flatfish and other benthic organisms which resulted in lower overlap indices. Unlike these and several other studies where flatfish were well represented in cormorant diets (Steven 1933, Pearson 1968, Mills 1969, Rae 1969, Cramp \& Simmons 1977, Pilon et al. 1983, Birt et al. 1987), few flatfish were recorded in this study. Diet breadth was also greater in Bitain (Table 9), a direct reflection of the greater prey diversity in the habitats studied. Our data come from more exposed and rocky habitats unfavourable to flatfish but where the low prey diversity was offset by the abundance of the most important prey (gadoids and sand eels). This plus the spatial separation of the localities compared suggest little competition between shags and cormorants. This conclusion concurs with that of Pilon et al. (1983) whose data also reveal high overlap indices $(0.87$ to 0.89$)$ and low effective competition between sympatric Phalacrocorax carbo and $P$. auritus in Quebec, Canada, where the main prey were also abundant. A similar analysis of Ross' (1976) data on the same species in Nova Scotia shows an overlap more similar to the British data $(0.34$ (nestling regurgitates by weight) -0.64 (adult pellets by number) and can be explained by different foraging habitats around the localities studied. Similarly in southwestern North America, the overlap indices between 3 Phalacrocorax species were low (0.1 to 0.5$)$, again as a direct result of feeding habitat diversity (Ainley et al. 1981).

\section{Implications for gadoid stock recruitment}

Most of the gadoids caught by shags and cormorants are probably saithe. In Norway, cod spawn from February to April in coastal waters mainly from Lofoten to West Finnmark, but also to a lesser extent off the southwest coast (Bergstad et al. 1987). By June-July most postlarvae and juveniles have drifted northwards to the Barents Sea where they remain until mature, although some remain in the northern fjords and over banks. Saithe also spawn early, mainly in February. The main spawning areas are further south than those of the cod (from Møre to Lofoten), and in contrast to cod fry which have an oceanic and coastal drift, most saithe fry soon move ashore to a littoral habitats and remain near the coast until 3 yr old (Bergstad et al. 1987).

There is no human exploitation of the youngest stages of gadoids in Nowegian waters. Though there are no biomass data for these fish, results of annual surveys by the Norwegian Institute of Marine Research (Bergen) have generated numerical estimates of these young fish available to potential predators along the coast and in the Barents Sea (Tables 10 and 11). Apart from 2 strong year classes of 0-group fish (in 1983 and 1985. Anonymous 1989, S. Sundby pers. comm.), the level of production of 0 -group cod has been poor $\left(<1000 \times 10^{6}\right.$ ind $\left.\mathrm{yr}^{-1}\right)$ since 1976 . Between 1946 and 1981 , the mean year-class strength of I-group saithe was $263 \times 10^{6}$ individuals $\left(\mathrm{SD}=110.5 \times 10^{6}\right.$, range 69 to $\left.464 \times 10^{6}\right) \mathrm{yr}^{-1}$ (from Jakobsen 1987). Since 1985 however, saithe recruitment has dropped by ca $40 \%$ $\mathrm{yr}^{-1}$ (Table 11). According to the values presented 
Table 9. Phalacrocorax aristotelis and P. carbo. Interspecies overlap (Morisita's index) in areas of sympatry and diversity (Shannon-Weaver index) of the diet of Norwegian and British cormorants and shags

\begin{tabular}{|c|c|c|c|c|}
\hline \multirow[t]{2}{*}{ Area } & \multirow[t]{2}{*}{ M. index } & \multicolumn{2}{|c|}{ S. W. index } & \multirow[t]{2}{*}{ Source } \\
\hline & & Shag & Cormorant & \\
\hline East Finnmark & $0.76)$ & & & \\
\hline Hovsflesa/Bleiksoy 1985 & 0.76 & & & This study \\
\hline Hovsflesa/Bleiksøy 1986 & $0.88)$ & & & \\
\hline Farne Islands & 0.50 & 0.34 & 0.78 & Pearson (1968) \\
\hline Cornwall & 0.11 & 0.56 & 0.51 & Lack (1945) \\
\hline River Dee & 0.55 & 0.73 & 0.75 & Rae (1969) \\
\hline Angus/Kincardineshire & 0.24 & 0.58 & 0.78 & Rae (1969) \\
\hline
\end{tabular}

Table 10. Gadus morhua. Numbers $\left(\times 10^{6}\right)$ of young cod along the coast of Norway and in the Barents Sea in poor, average and strong year classes. (Based on back-calculations from abundance estimates of III-group fish. From Hylen 1984)

\begin{tabular}{|ccrc|}
\hline $\begin{array}{c}\text { Age } \\
\text { group }\end{array}$ & Poor & $\begin{array}{c}\text { Size of year class } \\
\text { Average }\end{array}$ & Strong \\
\hline O & $300-600$ & $1100-2200$ & $2900-5800$ \\
I & $300-500$ & $1000-1900$ & $2700-4900$ \\
II & $200-300$ & $800-1100$ & $2200-3000$ \\
\hline
\end{tabular}

Table 11. Population indices (0-group saithe) and absolute numbers $\left(\times 10^{6}\right)$ of I- and II-group saithe and cod along the Norwegian coast and in the Barents Sea. (Based on 0-group surveys and VPA-analyses. From Mehl et al. 1988, Anon. 1990, Nedreaas pers. comm.)

\begin{tabular}{|lcrrrrc|}
\hline \multirow{2}{*}{$\begin{array}{l}\text { Age } \\
\text { group }\end{array}$} & \multirow{6}{c}{ Spawning year } \\
\hline Saithe & 0 & - & 828 & 545 & 285 & 165 \\
& I & - & 225 & 99 & 161 & $(200)$ \\
& II & - & 262 & 184 & 81 & - \\
Cod & I & 1091 & 258 & 196 & 286 & - \\
& II & 557 & 910 & 215 & 163 & 238 \\
& III & 386 & 464 & 758 & 179 & 136 \\
\end{tabular}

above, a consumption of 110 million I-group fish by shags and cormorants during the 4 summer months would alone be equivalent to $>20 \%$ of the total annual stock of I-group saithe and cod in 1985 to 1988 (range 295 to 483 million fish, Table 11). This estimate is unquestionably too high and potential inaccuracies in our data sets and those of the Norwegian Institute of Marine Research should be considered. For example, the estimation of stock sizes of the youngest classes of fish using single species VPA-analyses are often unreliable. Recent studies (Hildén 1988a) indicate that the mortality factors used for small fish in such analyses are not only generally too low, but also very sensitive such that small adjustments can result in large changes in the numbers of small fish available to predators. Furthermore, our diet data set is not neccessarily representative for the whole coast of Norway, nor do we have data for non-breeding birds. Nevertheless it seems that irrespective of prey species, the numbers of fish eaten by shags and cormorants are potentially high compared to the numbers apparently available and that predation by these species could affect the recruitment of young fish into 2 important commercial fisheries during years of low stock size.

The situation has recently been exacerbated by decreases in important prey species of the cod (capelin, prawn, herring) in 1986/87 resulting in considerable cannibalism of the youngest stages of cod spawned since 1984 such that even the recruitment of the strong 1984 to 1986 year-classes has been severely limited (S. Mehl pers. comm.). Levels of cannibalism (Mehl 1989) have been on the same order of magnitude as the apparent predation by shags and cormorants (Table 12). Keeping in mind that our estimations of predation only considered the 4 summer months (ringing data shows that both species are resident along the coast throughout the year (Myrberget 1973, Johansen 1975 , Galbraith et al. 1986, K.-B. Strann pers. comm., N. R. \& R. T.B. unpubl.), and even if they are overestimated by an order of magnitude, it seems possible that predation by shags and cormorants could be a factor limiting the

Table 12. The Northeast Arctic cod stock's consumption of young cod during the summer and autumn in tonnes $\left(\times 10^{6}\right)$ and numbers $\left(\times 10^{6}\right)$. (From Mehl 1989)

\begin{tabular}{|c|c|c|c|c|c|c|}
\hline \multirow{2}{*}{$\begin{array}{l}\text { Age } \\
\text { group }\end{array}$} & \multicolumn{3}{|c|}{ Biomass } & \multicolumn{3}{|c|}{ Numbers } \\
\hline & 1984 & 1985 & 1986 & 1984 & 1985 & 1986 \\
\hline 0 & - & 3 & 0.2 & - & 2506 & 85 \\
\hline I & 10 & 5 & 7 & 108 & 125 & 344 \\
\hline II & 1 & 11 & 23 & 13 & 41 & 158 \\
\hline III & + & - & 36 & + & - & 137 \\
\hline
\end{tabular}


build up of these 2 important fish stocks in the Northeast Atlantic. However, problems related to the systematic quantification of the natural mortality of fish attributable to other predators and of other factors regulating the populations of these early life stages of gadoid fish need to be resolved for managers (Hildén 1988b, Lapointe et al. 1989). More detailed studies of the species composition of gadoids, of possible seasonal and age-related variations in diets of shags and cormorants, their daily energy intake and of avian responses to changes in prey abundance are also required to further quantify any effects of predation by these birds. This study raises the importance of the consideration of predation by seabirds in fisheries multispecies modelling. It is also in sharp contrast with previous studies which all concluded that neither shags nor cormorants had any significant effect on commercial species. It is worth noting that cormorants and shags might also exert a favourable influence on fish populations by preying on heavily parasitized fish and by eating species that prey on commercially exploited fish (van Doben 1952).

Acknowledgements. This study was financed by the Norwegian Research Council for Science and the Humanities and the Norwegian Institute for Nature Research (R. T.B., N.R.), the Norwegian Directorate for Nature Management (N.R., J. L.) and the Natural Science and Engineering Research Council of Canada (W. A.M.). Further support was given by Tromsø Museum, the University of Tromsø and Fylkesmannen i Rogaland (Miljevernavdelingen). We thank H. M. Iversen, $\mathrm{H}$. Dransfeldt, K. Einvik, $\AA$. T Ekker and T Nygărd for their assistance in the field, and V. Frivoll for her help in sorting samples and identifying otoliths. We are also grateful to K. E. Erikstad, K. Nedreaas, S. Mehl and W. Vader for comments on this paper

\section{LITERATURE CITED}

Aebischer, N. J. (1986). Retrospective investigation of an ecological disaster in the Shag, Palacrocorax aristotelis: a general method based on long-term marking. J. Anim. Ecol. 55: 613-629

Ainley, D. G., Anderson, D. W., Kelly, P. R. (1981). Feeding ecology of marine cormorants in southwestern North America. Condor 83: 120-131

Anonymous (1989). Ressursoversikt for 1989 og miljørapport for 1988. Fisken Hav. 1989 (Særnr. 1)

Anonymous (1990). Report of the Arctic Fisheries Working Group Copenhagen, 19-28 September 1989. Coun. Meet. inst. Coun. Explor Sea, C. M. 1990/Assess:

Barlow, C. G., Bock, K. (1984). Predation of fish in fish dams by Cormorants, Phalacrocorax spp. Austr Wildl. Res. 11. 559-566

Barrett, R. T. Anker-Nilssen, T., Rikardsen, F., Valde, K., Røv, $N$, Vader, $W$ (1987). The food, growth and fledging success of Norwegian Puffin chicks Fratercula arctica in 1980-1983. Ornis Scand. 18: 73-83

Barrett. R. T., Furness, R. W (1990). The prey and diving depths of seabjirds on Horrøy, North Norway after a decrease in the Barents Sea capelin stocks. Ornis Scand. 21: in press
Barrett, R. T., Strann, K.-B., Vader, W. (1986). Notes on the eggs and chicks of North Norwegian Shags Phalacrocorax aristotelis. Seabird 9:3-10

Bergstad, O. A., Jorgensen, T., Dragesund, O. (1987). Life history and early ecology of the gadoid resources of the Barents Sea. Fish. Res. 5: 119-161

Birt, V. L., Birt, I P., Goulet, D., Cairns, D. K., Montevecchi, W. A. (1987). Ashmole's halo: direct evidence for prey depletion by a seabird. Mar. Ecol. Prog. Ser. 40: 205-208

Birt-Friesen, V. L., Montevecchi, W. A., Cairns, D. K. Macko, S. A. (1989). Activity-specific metabolic rates of freeliving Northern Gannets and other seabirds. Ecology 70: $357-367$

Breiby, A. (1985). Otolitter fra saltvannsfisker i Nord-Norge. Tromura Naturvit. 45: 1-30. Univ. Tromsø/Tromso Museum

Brown, R. G. B., Nettleship, D. N. (1982). Capelin and seabirds in the northwest Atlantic. In: Nettleship, D. N., Sanger, G A., Springer, P. F. (eds.) Marine birds: their feeding ecology and commercial fisheries relationships. Canadian Wildlife Service, Ottawa, p. 184-194

Cairns, D. K., Chapdelaine, G., Montevecchi, W. A. (1990). Prey exploitation by seabirds in the Gulf of St. Lawrence. Can. Bull. Fish. aquat. Sciences (in press)

Cramp, S., Simmons, K. E. L. (eds.) (1977). The birds of the Western Palearctic, Vol. 1. Oxford Univ. Press, Oxford

Craven, S. R., Lev, E. (1987). Double-crested Cormorants in the Apostle Islands, Wisconsin, USA: population trends, food habits, and fishery depredations. Colonial Waterbirds 10: $64-71$

Croxall, J. P. (ed.) (1987). Seabirds feeding ecology and role in marine ecosystems. Cambridge Univ. Press, Cambridge

Croxall, J. P., Prince, P. A., Ricketts, C. (1985). Relationhips between prey life-cycles and the extent, nature and timing of seal and seabird predation in the Scotia Sea. In: Siegfried, W. R., Condy, P. R., Laws, R. M. (eds.) Antarctic nutrient food cycles and food webs. Springer-Verlag, Berlin, Heidelberg, p. 516-533

Diamond, A. J. (1983). Feeding overlap in some tropical and temperate seabird communities. Stud, avian Biol. 8: $24-46$

Dobben, W. H. van (1952). The food of the Cormorant in the Netherlands. Ardea 40:1-63

Duffy, D. C., Jackson, S. (1986). Diet studies of seabirds: a review of methods. Colonial Waterbirds 9: 1-17

Duffy, D. C., Laurenson, L. J B. (1983). Pellets of Cape Cormorants as indicators of diet. Condor 85: 305-307

Dunn, E. H. (1975). Caloric intake of nestling Double-crested Cormorants. Auk 92: 553-565

Furness, R. W (1982). Seabird-fisheries relationships in the northeast Atlantic and Nurth Sea. In: Nettleship. D. N., Sanger, G. A., Springer, P. F. (eds.) Marine birds their feeding ecology and commercial. fisheries relationships. Canadian Wildlife Service, Ottawa, p. 162-169

Furness, R. W. (1990). A preliminary assessment of the quantities of Shetland sandeels taken by seabirds, seals, predatory fish and the industrial fishery in 1981-1983 Ibis 132: 205-217

Furness, R. W., Barrett, R. T (1985). The food requirements and ecological relationships of a seabird community in North Norway. Ornis Scand. 16: 305-313

Furness, R. W., Birkhead, T R. (1984). Seabird colony distions suggest competition for food supplies during the breeding season. Nature, Lond. 311: 655-656

Gabrielsen, G. W., Mehlum, F., Flint, E. N. (in press). Resting metabolic rate of six seabird species at St. Paul Island, Alaska. Physiol. Zoöl. 
Galbaith, H., Baillie, S. R., Furness, R. W., Russell, S. (1986). Regional variations in the dispersal patterns of Shags Phalacrocorax aristotelis in northern Europe. Ornis Scand. 17. $68-74$

Gales, R. P. (1988). The use of otoliths as indicators of Little Penguin Eudyptula minor diet. Ibis 130: 418-426

Gaston, A. J., Chapdelaine, G., Noble, D. G. (1983). The growth of Thick-billed Murre chicks at colonies in Hudson Strait: inter- and intra-colony variation. Can. J. Zool. 61: $2465-2475$

Härkönen, T. (1986). Guide to the otoliths of the bony fishes of the Northeast Atlantic. Danbiu ApS, Hellerup

Hartmann-Schröder, G. (1971). Annelida, Borstenwurmer, Polychaeta. Tierwelt Dtl 58: 1-594

Hildén, M. (1988a). Errors of perception in stock and recruitment studies due to wrong choices of natural mortality rate in virtual population analysis. J. Cons. int. Explor. Mer 44: 123-134

Hildén, M. (1988b). Significance of the functional response of predators to changes in prey abundance in multispecies virtual population analysis. Can. J. Fish. Aquat. Sci. 45: 89-96

Horn, H. S. (1966). Measurement of 'overlap' in comparative ecological studies. Am. Nat. 100: 419-424

Hunt, G. L., Jr, Eppley, Z. A., Schneider, D. C. (1986). Reproductive performance of seabirds: the importance of population and colony size. Auk 103: 306-317

Hylen, A. (1984). Yearclass strength of North-east Arctic cod at the 0-group stage. In: Dahl, E., Moksness, E., Solemdal, P. (eds.) The propagation of Cod Gadus morhua L. Flodevigen rapportserie, Vol. 1. Arendal 847-854

Hyslop, E. J. (1980). Stomach content analysis - a review of methods and their application. J. Fish Biol. 17: 411-429

Jakobsen, T (1987). Recruitment and distribution of northeast Arctic saithe in relation to changes in the environment. In: Loeng, $H$. (ed.) The effect of oceanographic conditions on distribution and population dynamics of commercial fish stocks in the Barents Sea. Proc, 3rd. Soviet-Norw. Symp., Murmansk, 26-28 May 1986, Inst. mar. Res., Bergen, p. 213-223

Jobling, M., Breiby, A. (1986). The use and abuse of fish otoliths in studies of feeding habits of marine piscivores. Sarsia 71: 265-274

Johansen, O. (1975). Forholdet mellom hekke- og overvintringssteder hos toppskarv i Norge som vist ved ringmerkingsgjennfunn. Sterna 14: 1-21

Johnstone, I. G., Harris, M. P., Wanless, S., Graves, J. A. (1990). The usefulness of pellets for assessing the diet of adult Shags Phalacrocorax aristotelis. Bird Study 37: 5-11

Junor, F. J. R. (1972). Estimation of the daily food intake of piscivorous birds. Ostrich 43: 193-205

Kennedy, G. J. A., Johnston, P. M. (1987). A review of salmon research on the River Bush. Proc. 17th Conf. Inst. Fish. Manage., Sept. 1986. Coleraine, N. Ireland

Lack, D. (1945). The ecology of closely related species with special reference to Cormorant (Phalacrocorax carbo) and Shag (P. aristotelis). J. Anim. Ecol. 14: 12-16

Lapointe, M. F., Peterman, R. M., MacCall, A. D. (1989). Trends in fishing mortality rate along with errors in natural mortality rate can cause spurious time trends in fish stock abundances estimated by virtual population analysis (VPA). Can. J. Fish. Aquat. Sci. 46: 2129-2139

Loeng, H. (ed.) (1987). The effect of oceanographic conditions on distribution and population dynamics of commercial fish stocks in the Barents Sea. Proc. 3rd. Soviet-Norw. Symp., Murmansk, 26-28 May 1986, Inst. mar. Res., Bergen, p. $1-250$
Lumsden, W. H. R., Haddow, A. J. (1946). The food of the Shag (Phalacrocorax aristotelis) in the Clyde Sea area. J. Anim. Ecol. 15: 35-42

Madsen, F. J., Spärck, R. (1950). On the feeding habits of the southern Cormorant (Phalacrocorax carbo sinensis Shaw). Dan. Rev. Game Biol. 1: 45-73

Mehl, S. (1989). The northeast Arctic cod stock's consumption of commercially exploited prey species in 1984-1986. Rapp. P.-v. Réun. Cons. int. Explor. Mer 1988: 185-205

Mehl, S., Nedreaas, K., Smedstad, O. M., Westgård, T. (1988). 0-group saithe and herring off the Norwegian coast in April--May 1988. Norw. Inst. Mar. Res. HELP Rep. No. 20

Mills, D. (1969). The food of the Cormorant at two breeding colonies on the east coast of Scotland. Scott. Birds 5: 268-276

Mironova, N. V. (1961). Biology of the Barents Sea saithe, Pollachius virens (L.). Int. Revue ges. Hydrobiol, 46: $447-459$

Moerbeek, D. J., Dobben, W. H. van, Osieck, E. R., Boere, G. C., Bungenberg de Jong, C. M. (1987). Cormorant damage prevention at a fish farm in the Netherlands. Biol. Conserv. 39: $23-38$

Myrberget, S. (1973). Merking av toppskarv og lunde på Røst. Sterna 12: 307-315

Nakken, O., Raknes, A. (1987). The distribution and growth of northeast Arctic cod in relation to bottom temperatures in the Barents Sea, 1978-1984. Fish. Res. 5: 243-252

Nedreaas, K., Smedstad, O. M. (1987). 0-group saithe and herring off the Norwegian coast in 1986 and 1987. Norw. Inst Mar Res. HELP Rep. No. 9

Pearson, T H. (1968). The feeding biology of sea-bird species breeding on the Farne Islands, Northumberland. J. Anim. Ecol. 37: 521-552

Pethon, P. (1985). Aschehougs store fiskebok. Aschehoug Oslo

Pilon, C., Burton, J., McNeil, R. (1983). Summer food of the Great and Double-crested Cormorants on the Magdalen Islands, Quebec. Can. J. Zool. 61: 2733-2739

Potts, G. R., Coulson, J. C., Deans, I. R. (1980). Population dynamics and breeding success of the Shag, Phalacrocorax aristotelis, on the Farne Islands, Northumberland. J. Anim. Ecol. 49: 465-484

Rae, B. B. (1969). The food or Coprmorants and Shags in Scottish estuaries and coastal waters. Dep. Agric. Fish. Scotland Mar Res. Nr 11

Reay, P. J. (1970). Synopsis of biological data on North Atlantic sandeels of the genus Ammodytes. F.A.O. Fish. Biol. Synopses No. 82

Ross, R. K. (1976). A comparison of the feeding and nesting requirements of the Great Cormorant (Phalacrocorax carbo L.) and Double-crested Cormorant ( $P$. auritus Lesson) in Nova Scotia. Proc. N. S. Inst. Sci. 27: 114-132

Ryan, B. F., Joiner, B. L., Ryan, T A. (1985). Minitab Handbook, 2nd edn. Dumbury, Boston

Røv, N. (1984). Storskarv og toppskarv. In: Røv, N. (ed.) Sjøfuglprosjektet 1979-1984. Viltrapp. 35. Trondheim, p. $59-64$

Røv, N., Strann, K.-B. (1986). The present status, breeding distribution, and colony size of the Cormorant Phalacrocorax carbo carbo in Norway. Fauna norv. (Ser. C. Cinclus) 10: $39-44$

Schneider, D. C., Hunt, G. L., Harrison, N. M. (1986). Mass and energy transfer to seabirds in the southeastern Bering Sea. Cont. Shelf Res. 5: 241-257

Steven, G. A. (1933). The food consumed by Shags and Cor- 
morants around the shores of Cornwall (England). J mar. biol. Ass. U. K. 19: 277-292

Tramer, E. J. (1969). Bird species diversity: components of Shannon's formula. Ecology 50: 927-929

Trayler, K. M., Bothers, D. J., Wooller, R. D., Potter, I. C.

This article was submitted to the editor
(1989). Opportunistic foraging by three species of cormorants in an Australian estuary. J. Zool., Lond. 218: 87-98

West, B., Cabot, D., Greer-Walker, M. (1975). The food of the Cormorant Phalacrocorax carbo at some breeding colonies in Ireland. Proc. R. Ir. Acad. (Ser. B) 75: 285-305

Manuscript first received: March 5, 1990 Revised version accepted. June 28, 1990 